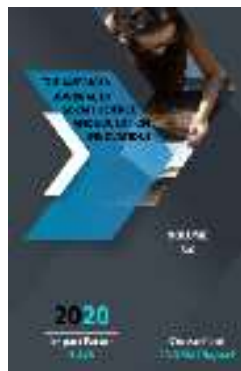

\title{
Formation Of The Spiritual Culture Of Primary School Teachers In The Conditions Of Informatization Of Education
}

\author{
Sidikova Zulfiyaxon Murodjon Qizi \\ Teacher Of The Department Of Primary Education Methodology Of Fergana State University, \\ Fergana Region, Uzbekistan
}

\begin{abstract}
Journal Website: http://usajournalshub.c om/index,php/tajssei

Copyright: Original content from this work may be used under the terms of the creative commons attributes 4.0 licence.
\end{abstract}

\section{ABSTRACT}

This article reveals the importance of pedagogical culture for education. There are various approaches to its definition. It considers the problems of the formation of pedagogical culture of future primary school teachers.

\section{KEYWORDS}

Culture, pedagogical culture, formation of pedagogical culture, primary school teachers, higher education, etc.

\section{INTRODUCTION}

The emergence of new needs and categories of life, among which the determining ones are the integration and globalization of social, economic and cultural processes, Uzbekistan's entry into the world economy and information space, in the time dimension of which, the ability to independently and actively act, take decisions, as well as flexibility to adapt to rapidly changing conditions of life, to think in accordance with the standards and requirements of dynamic cultural reality, to promote the rights of a human as the highest social value, disclosing its fullest capabilities, meeting diverse educational needs, ensuring priority of universal values, harmonizing relations of a human with the environment, society and nature becomes very important and requires development of new approaches to the formation of culture.

In a modern society, only a competent, independent and responsible personality with distinct civic position, i. e. an educated person, can upgrade the society, ensure independence 
of Uzbekistan; develop its economy and culture.

Unfortunately, over the last hundred years, the humanity, which has enriched in science, technology, in all spheres has moved much farther than during all ancient history, has made very little changes in itself. Instead, now it's time for pedagogy - time for improving an individual.

The object of the article is formation of pedagogical culture of future primary school teachers.

The purpose of this article is to determine the nature of pedagogical culture in higher education and to cover the most efficient ways of its formation.

The culture of teaching is a part of human culture. It embodies spiritual values of education (pedagogical knowledge, theories, concepts, gained teaching experience, professional ethics) and material values (training and education means), as well as methods of creative educational activities that contribute to socialization in specific historical conditions.

As modern school is reorienting according to demands of market structuring of all social life spheres in the state, the role of a teacher, as a central figure in organization of educational process, has changed. School needs a teacher who would perform his job professionally. There are grounds to talk about the tendency of diversification of teachers in terms of skill. The so-called elite teacher appears. His features are: professionalism, self-confidence, optimistic perception of the world, perseverance, creativity. Such a teacher has a sense of modernity in educational reality. He combines a narrow specialization with wide world outlook; he is always ready to master new forms, methods, technologies of training and education, providing confidence in the future.

\section{MATERIALS AND METHODS}

Today, a higher educational institution aims not only at providing knowledge, but also at shaping personality of a teacher, who, according to Tara's Shevchenko, would be an apostle of truth and science and personification of the nation's conscience, which requires a cultured teacher [2]. A cultured teacher is not a model of formal etiquette noble, but an intelligent person with his highest spiritual essence, with creative and humane way of worldview. Therefore, the problem "From an educated person to a cultured person", becomes particularly relevant today, which means revival of national intellectuals, creating domestic preconditions for development of creative individuality. Only in a cultural environment, specialists able to freely and widely think can emerge, and they can create intellectual values, which always were requested by society and by school in particular.

\section{DISCUSSIONS AND RESULTS}

The contemporary postnonclassical period in education development is characterized by transformation of the whole educational system into a subject-oriented one which is focused on self-fulfillment, spiritual, moral, emotional and axiological development of the personality [1]. Prioritizing innovative, proactive and creative human nature, this type of education is associated with the anthropocentric educational model as one of the mainstreams of contemporary educational theory. Following an anthropocentric and humanistic model of education in the context 
of constantly rising need for developing human capital [2] has made originally philosophical categories of "freedom" and "autonomy" commonly used in the context of pedagogy. Current situation in higher education in Russia requires implementation of a new type of training which puts emphasis on interests of the student with consideration for his or her personal experience, inclinations, abilities and professional commitment rather than on the previously used tactics of "trying to guess the right answer to the teacher's question". Taking into account the prerogative of the Russian universities to design their own programmers and develop new courses and training structures, this type of education involves actualization of a broad range of qualities and abilities by both students and teachers including goal-setting, important decision and rational choice making, self-appraisal and critical reflection on their own activities. Comprising the above-mentioned qualities, readiness for independent activity and continuous personal and professional development, it is autonomy that seems to be one of the most required personal characteristics in the current educational context. Accordingly, autonomous activity suggests the desire and readiness of the personality for relatively independent activity, critical reflection, important decision and rational choice making based on awareness of alternative options and their consequences.

For the formation of the readiness of future teachers of technology and entrepreneurship for the development of moral consciousness among schoolchildren, the following conditions are required: information and technological support for the stable interest of students in a new aspect of their professional training; inclusion of knowledge about morality in the content of educational disciplines of a technological profile on a successive basis; teaching students the ability to guide schoolchildren to find the moral meaning of various types of work; application of individual and collective forms of teaching students to the elements of organizing entrepreneurial activity during the period of pedagogical practices of students.

A modern day teacher in is expected to approach innovatively to the teaching process. First of all, we should define the "innovative teaching".

Innovative Teaching Methods is a new way of teaching which includes creativity, interactive $\&$ technology in teaching. Renewing traditional teaching to provide a new method of teaching to make learning better. Innovative teaching engages the student in the classroom \& develops an interest to learn.

The criteria and indicators of the readiness of the future teacher of technology and entrepreneurship for the development of moral consciousness in schoolchildren are:

- Value-oriented (orientation to the moral and semantic essence of labor and its entrepreneurial version, its production in future pedagogical activity; the need to acquire moral knowledge; internal motivation of readiness for the purposeful development of the moral consciousness of schoolchildren);

- Information and competence (knowledge of the morally developing capabilities of the academic subject, the moral and semantic resources of information technologies, the methodological foundations of the pedagogically directed 
process of developing the moral consciousness of schoolchildren);

- Activity-competence (the ability to direct schoolchildren to search for the moral meaning of various types of activity; organize training for schoolchildren in the elements of entrepreneurial activity; prepare them for moral choice in problematic situations of work, including entrepreneurial).

With that in mind, here is a comprehensive listing of the technology skills that every educator should have. Because as computer and associated technologies continue to change and evolve, educators must continue to strive for excellence in their work. Today that includes continued time and effort to maintain and improve their technology skills (as much as some educators do not want to admit).

\section{REFERENCES}

1. Acxiom Corporation (2011). Experiences verifying the identity of online students. Acxiom Corporation. Al-Alone, K. I. (2015). Learning Effects of Using Learning Management System (Moodle) by Students of Arab Open University. Pp.15-40.

2. Proceedings of MAC-ETel 2015. Multidisciplinary Academic Conference on Education, Teaching and E-Learning, Prague. Al-Amleh, M. (2014). Identifying the Palestinian Culture According To Hofstede's Theory. MA thesis, Jerusalem, occupied Palestinian Territories: Al-Quds University. Alkailani, M., Azzam, I. A., \& Athamneh, A. B. (2012). Replicating Hofstede in Jordan: ungeneralized, reevaluating the Jordanian culture. International Business Research, 5 (4), p.71.

3. American University in Cairo News (2015) Faculty Reform Requires Change in the Mindset of Educators, Youth [Online], Cairo. Available at: http://www.aucegypt.edu/news/storie s/faculty-reform-requireschangemindset-educators-youth (Accessed 27/11/2017) Assad, R., Salehi-Isfahani, D., \& Hendy, R. (2014). Inequality of opportunity in educational attainment in Middle East and North Africa: evidence from household surveys. In Economic Research Forum Working Paper Series No (Vol. 834). 